\title{
Length-weight relationship and relative condition factor of pearl oyster, Pinctada fucata martensii, cultured in the Tieshangang Bay of the Beibu Gulf, Guangxi Province, China
}

\author{
Leong-Seng Lim ${ }^{1 *}$, Isabella Ebi' ${ }^{1}$, Kit-Shing Liew ${ }^{1}$, Tzuen-Kiat Yap ${ }^{1}$, Cheng-Kai Shi², and Nai-Han Tan ${ }^{1,2}$ \\ ${ }^{1}$ Borneo Marine Research Institute, Universiti Malaysia Sabah, Jalan UMS, 88400 Kota Kinabalu, Sabah, Malaysia \\ ${ }^{2}$ Beihai Yuan Long Pearl Co. Ltd. Yunnan Road No. 285, Beihai, Guangxi, China
}

${ }^{*}$ Corresponding author: leongsen@ums.edu.my

\begin{abstract}
Tieshangang Bay in the Beibu Gulf, Guangxi of China, is a strategic location for pearl farming. Although water pollution has been reported in this bay but the general health of the pearl oyster, Pinctada fucata martensii, farmed there has never been assessed. The present study examined the condition of $P$. fucata martensii farmed in the Tieshangang Bay by analyzing its length-weight relationship (LWR) and relative condition factor (RCF). A total of 111 specimens were sampled for measuring their shell height and total weight for determining the LWR and RCF. The coefficient of correlation of the LWR was high $\left(\mathrm{R}^{2}=0.93\right)$, significant at 0.01 level. Negative allometric growth $(b=2.7048)$ was observed. However, $P$. fucata martensii achieved the expected growth in terms of weight, as determined through the RCF (mean 1.13). Negative allometric growth is commonly reported on the wild Pinctada spp. collected from different regions. Apparently, the water pollution in the Tieshangang Bay did not compromise the general health of the pearl oyster cultured there. Nevertheless, further study on the farm's surrounding water quality and plankton availability is necessary to investigate the interaction between the growth of the oyster and its culture environment. In conclusion, the P. fucata martensii farmed in the Tieshangang Bay was considered healthy and the bay is still suitable for pearl oyster farming.
\end{abstract}

Keywords: Pearl farming, Health assessment, Allometric growth, Water pollution

\section{Introduction}

China has been one of the major pearl producers in the world. The pearl oyster, Pinctada fucata martensii, has been cultured mainly in the Beibu Gulf, Guangxi of China for the pearl production (Gu et al., 2009; Wang et al., 2018). The Beibu Gulf of Guangxi has been known as China's Maritime Silk Road in the $21^{\text {st }}$ Century, and it is perceived as the gateway for the cooperation between China and the countries forming the Association of Southeast Asian Nations (ASEAN) (Yu and Lim, 2014). However, due to rapid industrialization and urbanization, the problem of water pollution in the Beibu Gulf has been increasing (Jiang et al., 2017; Chen et al., 2018). According to Jiang et al. (2017), water in the Tieshangang Bay, part of the Beibu Gulf, is also polluted by the discharge of industrial and residential wastes. Due to the semi-enclosed topography the water exchange rate in the Tieshangang bay is slow, causing accumulation of pollutants and worsening the water pollution in the bay ecosystem (Jiang et al., 2017). At present, there are several pearl oyster farms operating in this bay. Although the water pollution in the Tieshangang Bay has been assessed before but the general health condition of the pearl oysters farmed there was not investigated. Such information is necessary to find out if the bay is still suitable for the pearl oyster farming.

Length-weight relationship (LWR) is a common tool to assess the general health condition of the cultured aquatic animals. It can reflect their degree of wellbeing and adaptability to the environment (Fafuiye and Oluajo, 2005; Farzana and Saira, 2008; Lim et al., 2013). In fact, this tool is also applicable to bivalves, including the Pinctada species (e.g. Hwang et al., 2007; El-Sayed et al., 2011; Kalesaran et al., 2018). Derived from LWR calculation, the relative condition factor (RCF) can be computed to compare the observed to the expected condition of the animal (Fafuiye and Oluajo, 2005; Lim et al., 2013). The present study was aimed to examine the LWR and RCF of the pearl oyster $P$. fucata martensii cultured in the Tieshangang Bay.

\section{Materials and Methods}

\section{Collection of samples}

A total of 111 P. fucata martensii juveniles cultured at the Tieshangang Bay were randomly sampled on 3 March 2019 for the observations. These specimens were originally cultured in the mesh bags tied to the long-line system, owned by the Beihai Yuan Long Pearl Co. Ltd. They were removed from sea and transferred to the land facility for measurements. Figure 1 shows the location of the sampling station. 


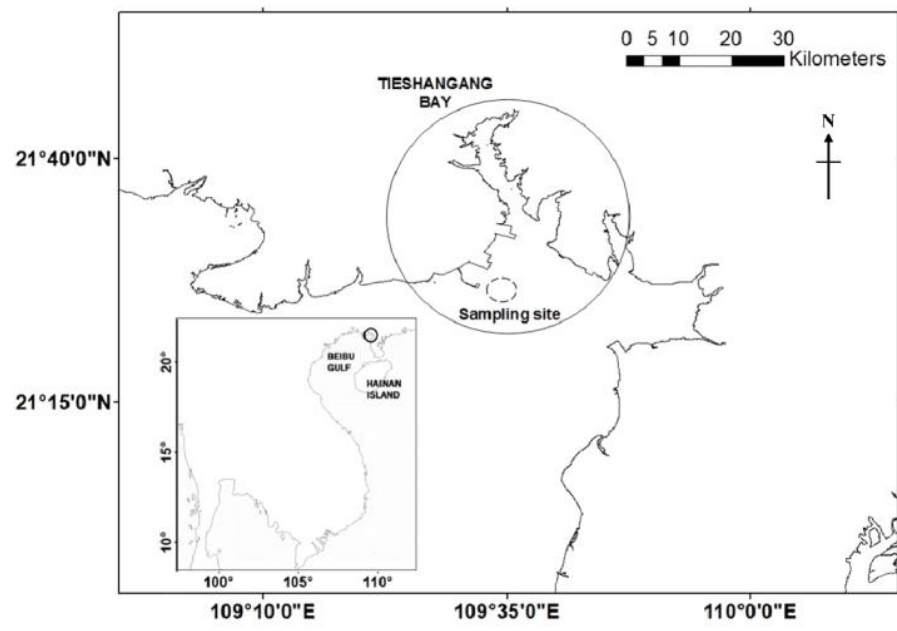

Figure 1. Location of the sampling site.

\section{Biometric measurement of specimens}

Prior to the measurements, the fouling animals on the shells of the oysters were removed manually by a sharp knife. Subsequently, each oyster was rinsed with tap water to wash out the mud and dirt, tap-dried using a towel, and measured close to 2 decimal points for its total weight (TW), shell height (SH), shell length (SL), shell width (SW), and hinge length (HL), following Hwang et al. (2007) (Figure 2). The oyster's TW was measured using a digital balance (I-2000, Shenzhen Laihui Electronics, China; standard error $\pm 0.01 \mathrm{~g}$ ); while the SH, SL, and SW, and HL were measured by a carbon fiber composites digital caliper (standard error $\pm 0.1 \mathrm{~mm}$ ). All the data were recorded in the computer software Microsoft Excel spreadsheet for further analysis. After the measurements, all oysters were returned to the culture facility. No mortality occurred from this examination.

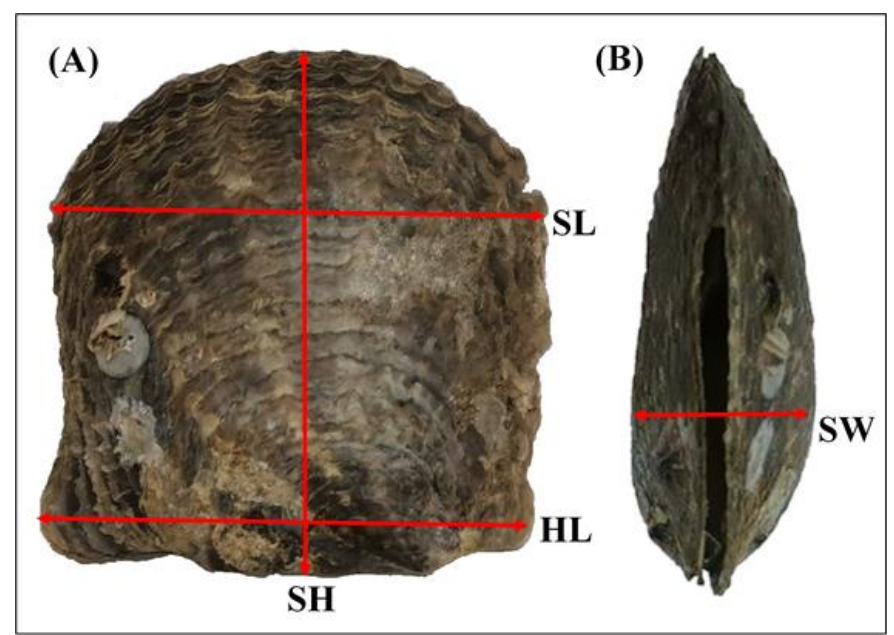

Figure 2. Biometric measurements of the pearl oyster, $P$. fucata martensii. (A) Plan view, (B) Side view of the pearl oyster. SL: Shell Length; HL: Hinge Length; SH: Shell Height; SW: Shell Width.

\section{Length-weight relationship (LWR) and relative condition factor (RCF) calculations}

LWR of the oysters was calculated with the formula $\mathrm{W}=a \mathrm{~L}^{b}$, where $\mathrm{W}=\mathrm{TW}$ and $\mathrm{L}=\mathrm{SH}$. Subsequently, linear regression graph was plotted based on the logarithmically-transformed formula $\ln \mathrm{W}=\operatorname{In} \mathrm{a}+\mathrm{b} \ln \mathrm{L}$, and the values of the constant $a$ and slope $b$ were estimated (Hwang et al., 2007; El-Sayed et al., 2011). The oyster attains isometric growth when $b=3$; negative allometric growth when $b<3$ or positive allometric growth when $b>3$ (Elamin and Elamin, 2014).

RCF was calculated using the formula $K n=100^{*} \mathrm{~W} / \mathrm{W}^{\prime}$, where $\mathrm{W}=$ is the observed weight, while $\mathrm{W}^{\prime}$ is the expected weight of an individual animal.

All the calculations and analyses were made using the Regression Data Analysis Tool in the Microsoft Excel Spreadsheet computer software. One-sample t-test was used to analyze the Coefficient of Correlation $\left(\mathrm{R}^{2}\right)$.

\section{Results}

\section{General biometric measurement}

Table 1 shows the values of weight and length of $P$. fucata martensii examined in the present study. TW range of the $P$. fucata martensii was $1.74-22.97 \mathrm{~g}$; SH was $23.00-57.60$ $\mathrm{mm}$; SL was $22.70-53.10 \mathrm{~mm}$; SW was $7-29.90 \mathrm{~mm}$; while HL was $21.40-53.50 \mathrm{~mm}$, respectively.

Table 1. Measurements of the $P$. fucata martensii sampled in this present study.

\begin{tabular}{lcc}
\hline $\begin{array}{l}\text { Biometric } \\
\text { parameters }\end{array}$ & Range & Mean \pm S. D. \\
\hline Total weight (TW) & $1.74-22.97 \mathrm{~g}$ & $11.62 \pm 4.62 \mathrm{~g}$ \\
& $23.00-57.60$ & $42.01 \pm 6.79$ \\
Shell height (SH) & $\mathrm{mm}$ & $\mathrm{mm}$ \\
& $22.70-53.10$ & $39.64 \pm 6.52$ \\
Shell length (SL) & $\mathrm{mm}$ & $\mathrm{mm}$ \\
& & $16.09 \pm 3.11$ \\
Shell width (SW) & $7.00-29.90 \mathrm{~mm}$ & $\mathrm{~mm}$ \\
& $21.40-53.50$ & $39.25 \pm 6.25$ \\
Hinge length (HL) & $\mathrm{mm}$ & $\mathrm{mm}$ \\
\hline
\end{tabular}

\section{LWR and RCF calculations}

The linear regression graph representing the TW - SH relationship of the P. fucata martensii is shown in Figure 3, and the estimated parameters of this relationship are listed in Table 2. This relationship was highly significant $\left(R^{2}=0.93\right.$, $\mathrm{P}<0.01)$. The $b$ value was $2.7048(<3)$, indicating that the $P$. fucata martensii attained negative allometric growth. Evidently, the specimens were growing faster in their shell height, instead of total weight. 


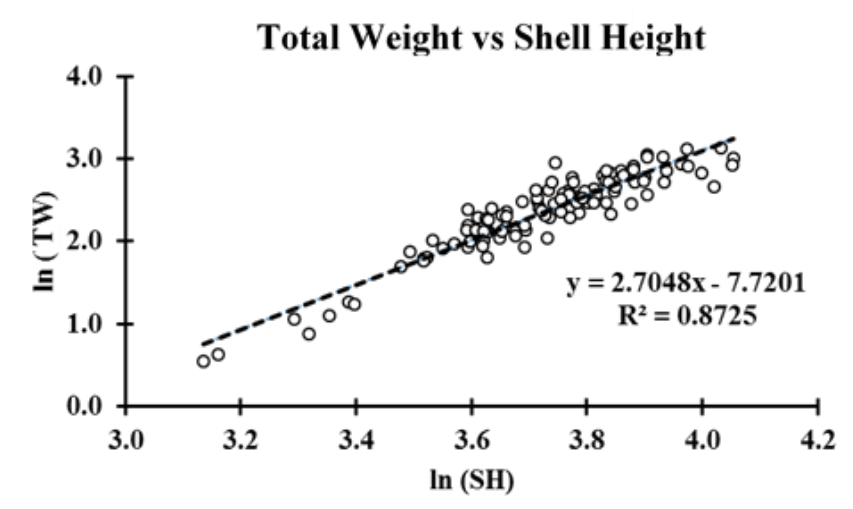

Figure 3. Linear regression of the TW - SH relationship of the sampled $P$. fucata martensii.

Table 2. Estimated parameters in the TW - SH relationship of $P$. fucata martensii through regression analysis.

\begin{tabular}{|c|c|c|}
\hline \multicolumn{2}{|c|}{$\mathbf{n}$} & 111 \\
\hline \multirow{2}{*}{$\begin{array}{c}\text { Total } \\
\text { Weight (g) }\end{array}$} & Min & 1.74 \\
\hline & Max & 22.9 \\
\hline \multirow{2}{*}{$\begin{array}{l}\text { Shell } \\
\text { Height } \\
\text { (mm) }\end{array}$} & Min & 23.00 \\
\hline & Max & 57.60 \\
\hline \multicolumn{2}{|c|}{$\ln a$} & -7.7201 \\
\hline \multicolumn{2}{|c|}{$\boldsymbol{b}$} & 2.7048 \\
\hline \multicolumn{2}{|c|}{ S.E. of $b$} & 0.0990 \\
\hline \multicolumn{2}{|c|}{$99 \%$ of C. I. } & $2.4452-2.9643$ \\
\hline \multicolumn{2}{|c|}{$99 \%$ of C. I. } & 0.87 \\
\hline
\end{tabular}

The $K n$ (mean \pm S.D.) of the P. fucata martensii was determined at $1.13 \pm 0.2(>1)$. This suggested that the pearl oyster achieved the expected growth in terms of weight.

\section{Discussion}

In the present study, the general health of $P$. fucata martensii sampled from the Tieshangang Bay can be considered as good based on the examined parameters. Although the oysters were growing faster in the shell height than the total weight (negative allometric growth), they achieved the expected growth (in weight) as indicated by the RCF. In fact, negative allometric growth has been commonly reported on the wild Pinctada spp. collected from different regions. Hwang et al. (2007) have reported the negative allometric growth of $P$. fucata, $P$. margaritifera, and $P$. sugillata collected from Taiwan. Moussa (2013) documented similar results on the $P$. radiata collected from 3 stations along the Egyptian Mediterranean coast of Alexandria. Elamin and Elamin (2014) also published data showing negative allometric growth of $P$. margaritifera var erythraensis collected from the Dongonab Bay, Red Sea. Recently, the negative allometric growth of P. margaritifera population in the North Sulawesi waters of Indonesia has been reported by Kalesaran et al. (2018). Water quality and natural food availability at the culture site are the key factors for the successful pearl oyster farming (Pouvreau et al., 2000; Tomaru et al., 2001, 2012; Yulianto et al., 2016). Apparently, the level of water pollution in the Tieshangang Bay did not cause a significant deterioration of the habitat and natural food items of $P$. fucata martensii at the cultured site to the extent of compromising the normal growth. Scope of the present study did not include collection of data on the surrounding water quality and natural food abundance of the culture site. Further studies are, therefore, required on the water quality and food supply in areas surrounding the culture site for a more comprehensive understanding of the effects of environmental variables on the pearl oyster production.

\section{Conclusions}

Pinctada fucata martensii farmed in the Tieshangang Bay was considered healthy, based on the LWR and RCF data. However, more follow-up studies on the surrounding water quality, and abundance and composition of plankton are required for a thorough assessment of the effect of environmental conditions on growth and condition of the pearl oyster.

\section{Acknowledgement}

The first author thanks the Science and Technology Department of Guangxi for providing a fellowship under the Guangxi Talented Young Scientist Program.

\section{References}

Chen, F.J., Lin, J., Qian, B.H., Wu, Z., Huang, P., Chen, K., Li, T.Y. \& Cai, M.G. (2018). Geochemical assessment and spatial analysis of heavy metals in the surface sediments in the Eastern Beibu Gulf: A reflection on the industrial development of the south China coast. International Journal of Environmental Research and Public Health 15, 496.

Elamin, E.M. \& Elamin, S.E.M. (2014). Biometric relationships of the mother of pearl oyster (Pinctada margaritifera var erythraensis) from Dongonab Bay, Red Sea. International Journal of Science, Environment and Technology 3, 1193-1204.

El-Sayed, A.E.H., Abdel Razek, F.A., Abou-Zaid, M.M. \& Taha, S.M. (2011). Measures of allometric growth of black-lip pearl oyster Pinctada margaritifera (Linnaeus, 1758) Red Sea, Egypt. International Journal of Zoological Research 7, 201-211.

Fafuiye, O.O. \& Oluajo, O.A. (2005). Length-weight relationships of five fish species in Epe Lagoon, Nigeria. African Journal of Biotechnology 4, 749-751. 
Farzana, Y. \& Saira, K. (2008). Length-weight relationship and relative condition factor for the Halfbeak Hemiramphus far Forsskål, 1775 from the Karachi Coast, University Journal of Zoology of Rajshahi University 27, 103-104.

Gu, Z., Wang, Q., Fang, J., Ye, N., Mao, Y., Shi, Y., Wang, Y. \& Wang, A. (2009). Growth of cultured pearl oyster (Pinctada martensii) in Li'an Lagoon, Hainan Island, China. Journal of Shellfish Research 28, 465-470.

Hwang, J.J., Yamakawa, T. \& Aoki, I. (2007). Growth of wild pearl oysters Pinctada fucata, Pinctada margaritifera and Pinctada sugillata (Bivalvia: Pteriidae) in Taiwan. Fisheries Science 73, 132-141.

Jiang, C.B., Liu, Y.Z., Long Y.N. \& Wu, C.S. (2017). Estimation of residence time and transport trajectory in Tieshangang Bay, China. Water 9, 321

Kalesaran, O.J., Lumenta, C., Mamuaya, G., Rompas, R. \& Watung, J. (2018). Biometric relationships of the black-lip oyster, Pinctada magaritifera from North Sulawesi waters, Indonesia. AACL Bioflux 11, 1587-1597.

Lim, L.S., Chor, W.K., Tuzan, A.D., Malitam, L., Gondipon, R. \& Ransangan, J. (2013). Length-weight relationships of the pond-cultured spotted barb (Puntius binotatus). International Research Journal of Biological Sciences 2, 61-63.

Moussa, R.M. (2013). Biometric studies of growth pattern affecting pearl production in pearl oyster Pinctada radiata. Egyptian Journal of Zoology 60, 397-415.

Pouvreau, S., Tiapari, J., Gangnery, A., Lagarde, F., Garnier, M., Teissier, H., Haumani, G., Buestel, D. \& Bodoy, A. (2000). Growth of the black-lip pearl oyster, Pinctada margaritifera, in suspended culture under hydrobiological conditions of Takapoto lagoon (French Polynesia). Aquaculture 184, 133154.

Tomaru, Y., Kawabata, Z. \& Nakano, S. (2001). Mass mortality of the Japanese pearl oyster Pinctada fucata martensii in relation to water temperature, chlorophyll a and phytoplankton composition. Diseases of Aquatic Organisms 44, 61-68.

Tomaru, Y., Kumatabara, Y., Kawabata, Z. \& Nakano, S. (2002). Effect of water temperature and chlorophyll abundance on shell growth of the Japanese pearl oyster, Pinctada fucata martensii, in suspended culture at different depths and sites. Aquaculture Research 33, 109-116.

Wang, Y.M., Sastra, L. \& Boonsom, Y. (2018). Pearl raising in Guangxi Province and its importance to the local economy. International Journal of East Asia Studies 22, 20-41.

Yu, H. \& Lim, W.X. (2014). The Guangxi Beibu Gulf economic zone and China's maritime silk road in the $21^{\text {st }}$ century. East Asian Policy 6, 16-29.

Yulianto, H., Hartoko, A., Anggoro, S. \& Delis, P.C. (2016). Suitability analysis of pearl oyster farming in Lampung Bay, Pesawaran, Lampung Province, Indonesia. AACL Bioflux 9, 1208-1219. 